\title{
Analysis of the Concept of Feasibility in Sustainable Agricultural Systems ${ }^{+}$
}

\author{
Lavinia Popescu and Adela Sorinela Safta *(D)
}

check for updates

Citation: Popescu, L.; Safta, A.S. Analysis of the Concept of Feasibility in Sustainable Agricultural Systems. Eng. Proc. 2021, 9, 13. https:// doi.org/10.3390/engproc2021009013

Academic Editors: Dimitrios Aidonis and Aristotelis Christos Tagarakis

Published: 24 November 2021

Publisher's Note: MDPI stays neutral with regard to jurisdictional claims in published maps and institutional affiliations.

Copyright: (c) 2021 by the authors. Licensee MDPI, Basel, Switzerland. This article is an open access article distributed under the terms and conditions of the Creative Commons Attribution (CC BY) license (https:// creativecommons.org/licenses/by/ $4.0 /)$.

\author{
Doctoral School Economics II, Bucharest University of Economic Studies, 010374 Bucharest, Romania; \\ popesculavinia14@stud.ase.ro \\ * Correspondence: saftaadela19@stud.ase.ro \\ + Presented at the 13th EFITA International Conference, online, 25-26 May 2021.
}

\begin{abstract}
The paper addresses through the new type concept the analysis of the feasibility of agricultural systems adaptable to environmental requirements. The development of a conceptual system for the feasibility of soil techniques through the responsible management of agricultural technological mechanisms can be expected to mitigate the impact of climate change. This paper analyzes the role of agricultural technologies based on the implementation of sustainable agriculture; as well as their interconnectivity in the local environment. In the methodological analysis was performed by compiling statistical data on agricultural production and effects of greenhouse gases (GHG) on agriculture
\end{abstract}

Keywords: feasibility; climate change; agricultural; greenhouse gas emissions

\section{Introduction}

There is a growing interest and numerous observations on land use that show different balances in feasible ecosystems by applying good management practices that have the role of streamlining the performance of soil with controlled fertilizers. Thus, the separate approach through case studies and the history of the soil, the agricultural systems are part of the entire value chain by reducing the negative impacts. Objectives such as the conservation and increase of biological diversity in competition with the projections caused by climate change can help reduce the negative impacts on rural areas in a separate approach. Reducing pollution, degrading soil and greenhouse gas emissions, maintaining biodiversity and maintaining balance by improving soil fertility call into question how much we actually rely on fertilizers and how we reduce consumption while maintaining the same yield [1] (Swinnen, 2015).

The assumption of carbon storage in soil could be an option to mitigate climate change for agriculture, by managing the land and changing its use. In this study, we examine the possibility of adapting the methods used to estimate soil carbon changes.

\section{The Issue of Climate Change}

In the first instance, the evolution of agricultural systems has always had an effect on other systems. The resettlement of key pawns that form the study of agricultural systems. It has become vital to investigate agricultural models with innovative alternative practices that reduce greenhouse gas emissions, biodiversity loss, and soil erosion. The interdependent relationship between carbon sequestration in soil and climate change led to the idea of the need to find new methods of conserving agriculture, as argued by Popescu, L. et al. (2021) [2]. On the other hand, the sustainability of agricultural ecosystems can be applied separately, depending on the ecosystem, to give efficiency, the process being cyclical, therefore, in conditions of climate risk and the agricultural system suffers from the natural ecosystem [3]. The planet offers countless benefits to our individual well-being and the well-being of our societies and economies. According to investigations conducted 
in the Intergovernmental Panel on Climate Change (IPCC), global warming is a definite fact highlighted by the increase in global average air and ocean temperatures and more. As a consequence, in addition to the elements mentioned, climate change also attracts by changing the frequency and/or intensity of extreme risks of natural phenomena. On the other hand, other studies have shown that soil respiration with $\mathrm{CO}_{2}$ is reduced in chronic fertilization. Against this background, a number of agricultural systems have emerged as having the potential to increase soil carbon, through land use, productivity. It is important to consider the emission of these greenhouse gasses (GHGs) when evaluating various practical agricultural products for their carbon sequestration potential, as well as among the most comprehensive attempts to estimate the global potential for GHG mitigation is a paper by the IPCC Working Group on Mitigation (Smith et al., 2012) [4,5].

\section{Results}

With the introduction of cross-compliance in agricultural systems in response to climate change, it was initially introduced as a formality in the Common Agricultural Policy (CAP) in the previous multiannual financial framework, with an emphasis on increasing the sustainability of agricultural systems to facilitate climate change mitigation. Agroecosystems can be divided into cultivated land and meadows as indicated in Table 1. Spatial nutrition enhances agro-ecosystems and therefore studies the environment with the aim of synthesizing the succession of technological flows related to the main agri-food sectors as claimed. The data in Table 1 show ecosystem extent trends for all tier II ecosystem categories between 2000-2018, and suggest that the area of $\mathrm{N}$ entry category of $<50 \mathrm{~kg} / \mathrm{ha}$ has increased, while the surface share of all Nitrogen (N) entry levels decreased between 2000 and 2018. This confirms that the overall contribution of $\mathrm{N}$ to agricultural land decreased during the study period and that areas of especially high nutrient pressures decreased to some extent. Differentiation of grasslands into subtypes by ecological characteristics and sensitivity to $\mathrm{N}$ input is necessary to make the accounting of spatial conditions as strong as analytically possible.

Table 1. Ecosystem extent trends for all tier II ecosystem categories between 2000-2018, EU28.

\begin{tabular}{ccccc}
\hline \multirow{2}{*}{ Tier I } & Title 2 & Area $\left.\mathbf{2 0 0 0} \mathbf{( k m}^{\mathbf{2}}\right)$ & Area 2018 $\mathbf{( k m}^{\mathbf{2}} \mathbf{)}$ & Net Change (\%) \\
\hline \multirow{4}{*}{ Cropland } & Arable land & $1,105,007$ & $1,095,846$ & -0.8 \\
\cline { 2 - 5 } & Rice fields & 6500 & 6559 & 0.9 \\
\cline { 2 - 5 } & Permanent crops & 117,835 & 119,990 & 1.8 \\
\cline { 2 - 5 } & Mixed farmland & 375,523 & 373,727 & -0.5 \\
\cline { 2 - 5 } & Total cropland & $1,604,865$ & $1,596,122$ & -0.5 \\
\hline \multirow{3}{*}{ Grassland } & $\begin{array}{c}\text { Modified } \\
\text { grassland }\end{array}$ & 398,203 & 394,608 & -0.9 \\
\cline { 2 - 5 } & $\begin{array}{c}\text { Semi-natural } \\
\text { grassland }\end{array}$ & 106,646 & 106,029 & -0.6 \\
\cline { 2 - 5 } & Total grassland & 504,849 & 500,637 & -0.8 \\
\hline
\end{tabular}

Source: Eurostat data 2020.

Nutrient enrichment is a key indicator of pressure for the condition of the ecosystem, negatively affecting all terrestrial and aquatic ecosystems. The entry of $\mathrm{N}$ into agroecosystems is a consequence mainly of agriculture but also of the atmospheric deposition of emissions from transport, energy and industry. As shown in Figure 1a greenhouse gases are assessed spatially and the level at which we should act to counteract the effects of climate pollution from agricultural sources can avoid the constraints of effective soil reduction. It becomes evident that the feasible adaptation of processes in agricultural practice that generally reduce soil degradation could keep carbon dioxide underground, the spatial exposure achieved in Figure 1a,b Ecosystem categories between 2000-2018, Net change. 
It becomes clear that the biosphere helps a great deal in reducing $\mathrm{CO}_{2}$ emissions from the atmosphere. Figure 2 shows the many different types of data that need to be brought together in a common spatial framework, ranging from biodiversity monitoring data to agricultural statistics [6,7].

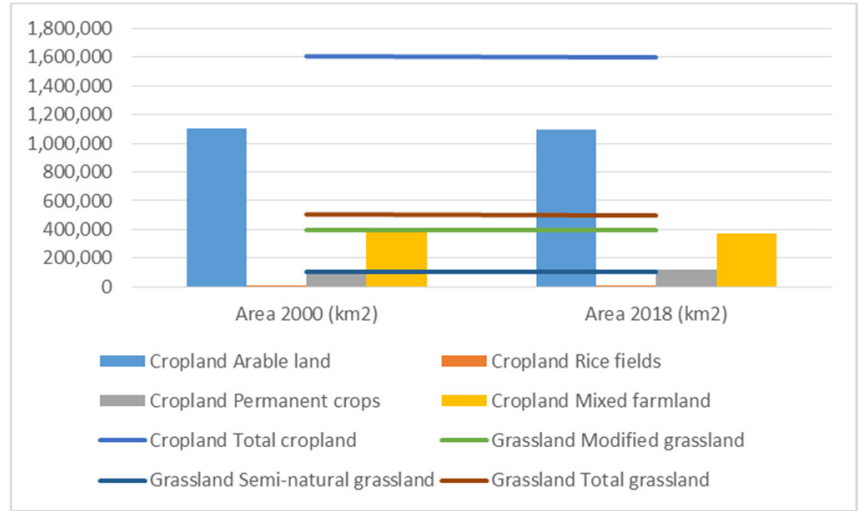

(a)

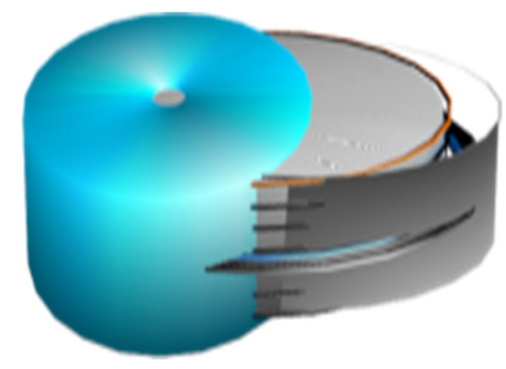

(b)

Figure 1. Ecosystem categories between 2000-2018, Net change, Source: Authors' research. (a) graphic presentation; (b) spatial presentation.

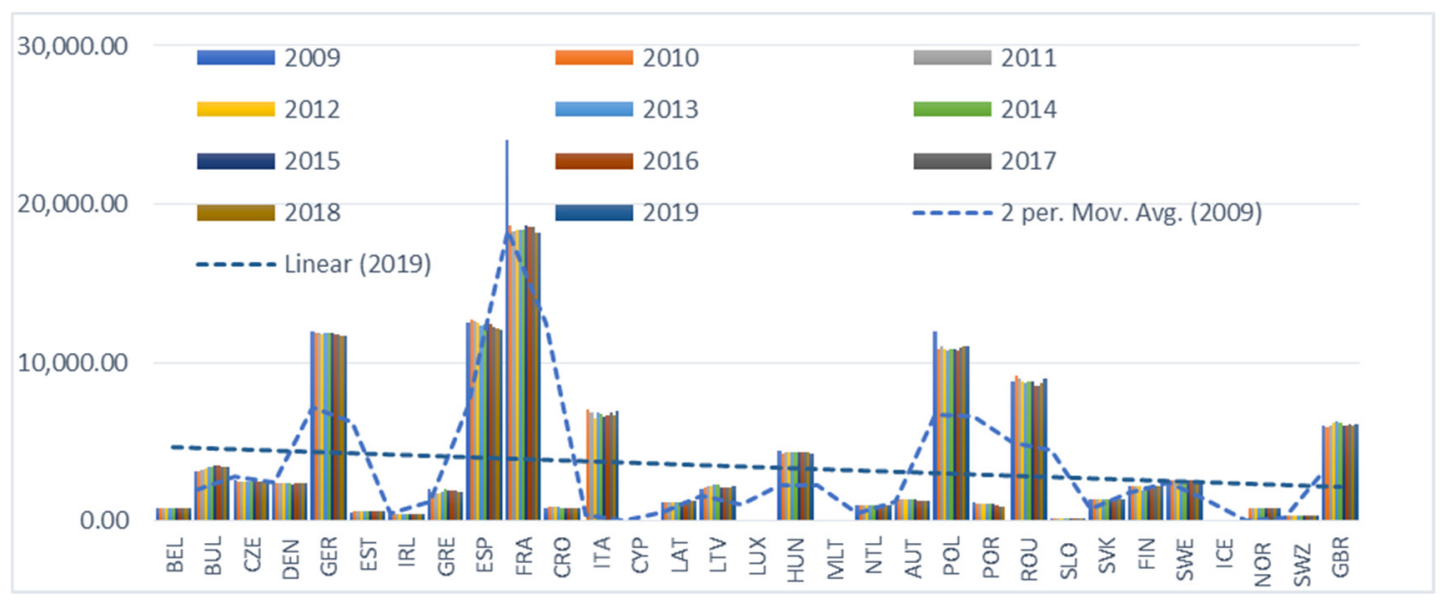

Figure 2. Utilised agricultural area by categories. Sources: European Commission, Eurostat and Directorate General for Agriculture and Rural Development.

\section{Discussion and Conclusions}

Investigating carbon storage and soil use feasibility strategies creates premises for reducing greenhouse gas emissions. In terms of the agricultural context, the economic system of sustainability creates the perception of a future benefit for the environment, with agricultural producers being obliged to comply with environmental requirements.

The interdependent relationship between carbon sequestration in soil and climate change has led to the need of finding new methods of conserving agriculture. The implementation of sustainable agricultural production can lead to an increase in carbon sequestration in soil through proper land management, thus making it possible to improve its properties [8]. The evolutions of carbon sequestration in soil are an important method and a priority.

On the other hand, the vision of the Common Agricultural Policy is an open door for agricultural producers to strive for sustainable management of natural resources burdened by the pressures of climate change. Thus, farmers are active participants in the sustainability of agricultural ecosystems step by step. This concept of standardization of agriculture can 
be adapted to the needs of the ecosystem to give efficiency. The resumption of annual agricultural practices does not necessarily lead to the standardization of agricultural processes, the innovation consisting even in changing these paradigms. The disadvantage of climate imbalances must be approached from another angle because in conditions of climate risk and the agricultural system suffers and farmers must be able to respond to these changes [9]. Thus, the monitoring of ecosystem forecasting trends as a condition of predictability gives rise to the need of investigating disruptive links, such as forcible cases due to climate change. Forecasting as a condition of feasibility of production methods based on the integration of natural resources and the biosphere is authors' vision of integration in the agricultural ecosystem, as an integral part of the rural space. Therefore, the relationships investigated in the present research should also be analyzed in dynamics, by conducting a longitudinal study, in order to increase the predictive power of the proposed conceptual model of feasibility. The empirical research undertaken in this paper has highlighted the fact that there is a need to position the effects in terms of the causes that produced them, so the relationship between greenhouse gases is influenced by the environment in which they are generated. Hence the need to revise production models predictable to the risk of climatic conditions in agricultural systems. This vision arises from the obligations imposed by the new CAP conditionality on meeting the target of reducing greenhouse gas emissions from agriculture [10]. Therefore, future research could aim at transforming multidimensional agricultural processes to ensure adaptation efforts. This vision is also based on the practice of intensifying feasibility models in agriculture to increase yields, while respecting environmental conditions. This has led to far-reaching implications for shaping the predictable behavior of producers either among local entrepreneurs or farmers. Taking into account the properties of the soil, we investigated through the $S_{\text {phor }}$ coefficient the relationship of conditionality between climate and production monitoring as vital characteristics for the emissions perspective.

Author Contributions: Methodology by L.P. and developed by A.S.S. All authors have read and agreed to the published version of the manuscript.

Funding: This research received no external funding.

Conflicts of Interest: The authors declare no conflict of interest.

\section{References}

1. Colen, L.; Swinnen, J. Economic Growth, Globalisation and Beer Consumption. J. Agric. Econ. 2015, 67, 186-207. [CrossRef]

2. Popescu, L.; Safta, A.S. The Causal Relationship of Agricultural Standards, Climate Change and Greenhouse Gas Recovery. Environ. Sci. Proc. 2021, 4, 21. [CrossRef]

3. Aznar-Sánchez, J.A.; Piquer-Rodríguez, M.; Velasco-Muñoz, J.F.; Manzano-Agugliaro, F. Worldwide research trends on sustainable land use in agriculture. Land Use Policy 2019, 87, 104069. [CrossRef]

4. IPCC. IPCC Guidelines for National Greenhouse Gas Inventories; Workbook; Intergovernmental Panel on Climate Change: Paris, France, 1997. Available online: https:/ / www.ipcc.ch/ (accessed on 12 April 2021).

5. Smith, P.; Davies, C.A.; Ogle, S.; Zanchi, G.; Bellarby, J.; Bird, N.; Boddey, R.M.; McNamara, N.P.; Powlson, D.; Cowie, A.; et al. Towards an integrated global framework to assess the impacts of land use and management change on soil carbon: Current capability and future vision. Glob. Chang. Biol. 2012, 18, 2089-2101. [CrossRef]

6. European Commission. Environment Action Programme to 2020. Available online: https: / / ec.europa.eu/environment/actionprogramme/ (accessed on 12 April 2021).

7. Eurostat Data. 2020. Available online: https://ec.europa.eu/eurostat/documents/7870049/12943935/KS-FT-20-002-EN(accessed on 22 April 2021).

8. Pugh, T.A.M.; Arneth, A.; Olin, S.; Ahlström, A.; Bayer, A.D.; Goldewijk, K.K.; Lindeskog, M.; Schurgers, G. Simulated carbon emissions from land-use change are substantially enhanced by accounting for agricultural management. Environ. Res. Lett. 2015, 10, 124008. [CrossRef]

9. Rodrigo-Comino, J.; Martinez-Hernandez, C.; Iserloh, T.; Cerda, A. Contrasted impact of land abandonment on soil erosion in Mediterranean agriculture fields. Pedosphere 2018, 28, 617-631. [CrossRef]

10. Westhoek, H.; Lesschen, J.P.; Rood, T.; Wagner, S.; De Marco, A.; Murphy-Bokern, D.; Leip, A.; van Grinsven, H.; Sutton, M.A.; Oenema, O.; et al. Food choices, health and environment: Effects of cutting Europe's meat and dairy intake. Glob. Environ. Chang. 2014, 26, 196-205. Available online: http:/ / www.sciencedirect.com/science/article/pii/S095937801400338 (accessed on 12 April 2021). [CrossRef] 